\title{
Bathymetric and chemical analysis of an ox-bow lake in view of aquaculture
}

\begin{abstract}
Oxbow lakes provide most appropriate environment for aquaculture in deltaic plain. Nawpara Beel (swamp/lake) is the largest of five major oxbow lakes in the Community Development Block (CD Block) of Krishnagar -II. But for years it is left fallow and no aquaculture is being practiced for development of the poor fishermen community on its levees. Present paper studied channel morphometry and chemical quality of water in view of aquaculture in the beel. Variables of plan form geometry like radius of curvature, arc angle; bathymetric analysis of channel and water quality of the oxbow lake in terms of aquaculture were tested. Bathymetrically the beel is suitable for different type of aquaculture but water quality is not suitable for all type of aquaculture.
\end{abstract}

Keywords: Nawpara beel, Oxbow lake, Aquaculture, Water quality, Bathymetry
Volume 6 Issue 6 - 2017

Balai Chandra Das
Department of Geography University of Kalyani India

Correspondence: Balai Chandra Das Department of Geography Krishnagar Govt College under University of Kalyani West Bengal India, Tel 919475184957,

Email drbalaidaskg@gmail.com

Received: December 07, 2017 | Published: December 22, 2017
Abbreviations: $\mathrm{A}^{*}=$ Channel Asymmetry; $\mathrm{A}_{1}=$ Cross-Sectional area to the left of the Channel Centerline; $A_{r}=$ Cross-Sectional Area to the right of the Channel Centerline; $\mathrm{BDO}=$ Block Development Officer; $\mathrm{BOD}=$ Biological Oxygen Demand; $\mathrm{CD}$ Block = Community Development Block; $\mathrm{C}_{\mathrm{f}} \mathrm{I}=$ Channel Form Index; $\mathrm{COD}=$ Chemical Oxygen Demand; $\breve{D}=$ Depth of the most Efficient Channel; $d=$ Observed Depth of the Channel; DO= Dissolved Oxygen; $I_{d}=$ depth index; $I_{w}=$ width index; $L A P=$ Least Action Principle; $r_{c=}$ Radius of Curvature; $r=$ Radius of the Channel Cross-Section when it is Semicircular in Shape (ẃ/2); W = Observed Width of the Channel; w $=$ Width of the most Efficient Channel; $\Theta=$ Arc Angle

\section{Introduction}

Wetlands are areas where water is the primary factor controlling the environment and the associated plant and animal life. ${ }^{1}$ They occur where the water table is at or near the surface of the land, or where the land is covered by water. Once treated as transitional habitats or seral stages in succession from open water to land, the wetlands are now considered to be distinct ecosystems ${ }^{2,3}$ with specific ecological characteristics, functions and values. According to most widespread definition, wetlands are defined as: "lands transitional between terrestrial and aquatic eco-systems where the water table is usually at or near the surface or the land is covered by shallow water" ${ }^{4}$ Ramsar Convention on Wetlands defines wetlands as: "areas of marsh, fen, peat land or water, whether natural or artificial, permanent or temporary, with water that is static or flowing, fresh, brackish or salt, including areas of marine water the depth of which at low tide does not exceed six metres". In addition, for the purpose of protecting coherent sites, the Article 2.1 provides that wetlands to be included in the Ramsar List of internationally important wetlands "may incorporate riparian and coastal zones adjacent to the wetlands, and islands or bodies of marine water deeper than six metres at low tide lying within the wetlands".

It is increasingly realized that the planet earth is facing grave environmental problems with fast depleting natural resources and threatening the very existence of most of the ecosystems. Depletion of Wet lands is one of such serious concern being voiced among scientists, planners, sociologists, politicians, and economists to conserve and preserve. These water bodies are the kidneys of the environment. They sieves pollutants and toxic elements from water and provide fresh water for numerous lives living in wetlands. Wetlands are highly fertile with adequate nutrients for planktons, algae and other plants which are in turn the huge storehouse of food for aquatic animals. Fish, especially inland-water fish is the staple food for Bangalee. But greedy activities without any considerations of its consequences, leads those wetlands to deterioration rapidly. Irrational uses of lands are leading to progressive rate of siltation and rapid decrease in area and volume of wetlands. Moreover wetlands in urban and rurban areas are being closed at an alarming rate for constructional works.

Existing wetlands with lesser area and volume, receives thousands of tons of pollutants generated and induced by activities of modern man intoxicated by the power he has acquired through his scientific inventions and technological skills. ${ }^{5} \mathrm{He}$ has the one and only one motive of profit maximization. But closing or deterioration of wetlands are same as the damaged kidney in mammals which demands regular dialysis increasing living cost beyond capacity.

Tasty inland fishes are very rich in nutrients which provide the best diet for the inhabitants of the area concerned. But the number and variety of fishes have decreased sharply along with their nutrient quality and taste within few decades.

But slight change in the direction in the human motive could give remarkable but sustainable development for the whole community, not for one or two. Fate of wetlands of Nadia District is not different from said above. We have 176 wetlands $^{6}$ in the district with total area of $189 \mathrm{~km}^{2}$ and capacity of $159000000 \mathrm{~m}^{3}$. Nadia district shares $7.7 \%$ of total inland fresh water bodies of West Bengal and natural wetlands (beels) constitute lion share of these inland water bodies. Average production from these beels is only $500-1000 \mathrm{~kg} /$ hectare / year which can be raised $2000-3000 \mathrm{~kg}$ / hectare / year. ${ }^{7}$ On 'Matsya Chas Bisayak Aalochona Chakra' organized by Nadia Zila Parishad and Fishery Department, Nadia it was reported that production of these beels (wetlands) under fishermen co-operative society was only 100 $\mathrm{kg} /$ hectare / year. ${ }^{8}$

In C. D. Block Krishnagar - II, there are seven large wetlands. Most of them are with same fate as said before. But we could fuel our machinery of village - development with a sustainable but satisfactory speed by proper management of these beels (wetlands). We could get arsenic - free surface water for drinking, irrigation and cottage industries; water hyacinths and other aquatic weeds to manure our agricultural lands to have bumper production; fishes of high nutrients and taste which has mountain-peak market demand 
and price; vast extent of water bodies to promote duck farming and habitats for migrant birds. From the wetlands of Nadia district as many as 42 species of angiosperms belonging to 26 families and 2 species of pteridophytes were observed which are locally used for various purposes. Of these plants, 30 species have excellent medicinal properties. ${ }^{9}$ Therefore proper management and use of these beels can make a miracle to the development of the weaker sections of the society who are dependent for their livelihood on those wetlands. But foremost task is knowing the beel- its bathymetry, water and biology. In this context present paper tried to bathymetric and chemical analysis of an ox-bow lake in view of aquaculture.

\section{Materials and methods}

Variables of plan form geometry ${ }^{10,11}$ of the oxbow lake like radius of curvature $\left(r_{c}\right)$ and arc angle $(\theta)$ were measured from satellite image. Bathymetric survey of the beel (oxbow lake) was done using GOL 26 Auto Level and accessories. On the basis of 18 cross sections along the beel, contour lines were drawn for understanding of inchannel terrain. Channel asymmetries $\left(\mathrm{A}^{*}\right)$ at 18 cross-sections were measured using formulae-

$$
A^{*}=\frac{\left(A_{r}-A_{l}\right)}{A}[12]
$$

Where $A_{r}$ and $A_{l}$ represent right and left part of cross-sectional area to the channel centre line and $A=A_{r}+A_{1}$

Ideal width (ẃ) of a channel provides tool to compare width of a natural channel of given cross-sectional area to that of the ideal width which the channel tries to follow least action principle (LAP) (Nanson, 2017). ${ }^{13} \dot{w}$ is defined as $2 \mathrm{r}$ when channel crosssection is semicircular in shape and calculated as w $=1.595 \sqrt{ } \mathrm{A}$. and width index (Iw) is defined as-

$$
I_{w}=w / w
$$

Where $\mathrm{w}=$ observed width of the channel. Width index $\left(\mathrm{I}_{\mathrm{w}}\right)$ is a numerical tool to compare the shape of the river cross-sectional form, whether its width matches the width of most efficient channel or how much deviated from it. If $I_{w}=1$, the width matches perfectly.
$>1$ indicate wider and $<1$ indicate narrower channel. Ideal Depth (Ľ) provides tool to compare depth of a natural channel of given crosssectional area to that of the ideal depth which the channel tries to attain for best conveyance. $\mathrm{D}$ is defined as $\mathrm{A} / \mathrm{w}$ and depth index (Id) is defined as-

$$
I_{d}=d / D
$$

Where $d=$ observed mean depth of the channel. Depth index $\left(I_{d}\right)$ is a numerical tool to compare the shape of the river cross-sectional form, whether its depth matches the depth of most efficient channel or how much deviated from it. If $\mathrm{Iw}=1$, the depth matches perfectly. $>1$ indicates deeper and $<1$ indicates shallower channel.

Whether a channel cross - section is relatively shallower or deeper can be readily measured by using channel form index $\left(C_{F} I\right)$ which is formulated as-

$$
\left(C_{f} I\right)=\frac{W / d}{2.54}[14]
$$

Zero, the lowest value of the index indicate extremely narrow channel. 1 indicates ideal width depth ratio above which larger is the value wider and shallower is the channel. Water quality was diagnosed using method APHA $21^{\text {st }}$ Edition.

\section{Results and discussion}

Nawpara Beel is an oxbow-lake originated as a rejected channel of the river Jalangi during late $18^{\text {th }}$ or early $19^{\text {th }}$ century (Das, 2013). Its geographical location is marked by latitudinal extension from $23^{\circ}$ $29^{\prime} 51^{\prime \prime} \mathrm{N}$ to $23^{\circ} 31^{\prime} 04^{\prime \prime} \mathrm{N}$ and longitudinal extension from $88^{\circ} 28^{\prime}$ $40^{\prime \prime} \mathrm{E}$ to $88^{\circ} 29^{\prime} 33^{\prime \prime} \mathrm{E}$ (Table $1 \& 2$ ). Length of beel is $4.9 \mathrm{~km}$ with perimeter $9.86 \mathrm{~km}$. Radius of curvature $(\mathrm{r})$ of apex bend is $320 \mathrm{~m}$ and of major curve is $897 \mathrm{~m}$. Longest distance of the beel from its mother river Jalangi, where from neck cut took place, is $3.04 \mathrm{~km}$. The beel is deepest (>12 meters) to the north-west mid of the major curve and shallows gradually to be erased out to the south where from it was cut-off (Figure $1 \& 2$ ).

\begin{tabular}{|c|c|c|c|c|c|c|c|c|c|c|}
\hline Item & A & w & d & $w / d$ & ẃ & IW & Ď & Id & Cfl & $A^{*}$ \\
\hline Average & 904.64 & 211.87 & 4.19 & 63.46 & 46.30 & 4.85 & 19.51 & 0.20 & 24.95 & 00.026 \\
\hline SD & 493.39 & 26.57 & 2.17 & 34.72 & 13.31 & 1.26 & 5.61 & 0.05 & 13.65 & 00.001 \\
\hline $\mathrm{CV}$ & 0.55 & 0.13 & 0.52 & 0.55 & 0.29 & 0.26 & 0.29 & 0.25 & 0.55 & 00.120 \\
\hline
\end{tabular}

Table I Magnitude of plan view dimensions of Nawpara Beel

\begin{tabular}{lll}
\hline I. No. & Item & Value \\
\hline $\mathrm{I}$ & Location & Latitude: $23^{\circ} 29^{\prime} 5 \mathrm{I}^{\prime \prime} \mathrm{N}$ to $23^{\circ} 3 \mathrm{I}^{\prime} 04^{\prime \prime} \mathrm{N}$ \\
2 & Length & Longitude: $88^{\circ} 28^{\prime} 40^{\prime \prime} \mathrm{E}$ to $88^{\circ} 29^{\prime} 33^{\prime \prime} \mathrm{E}$ \\
3 & Average width & $4.9 \mathrm{~km}$ \\
4 & Radius of curvature & 211.87 meters \\
& & For minor curve 320 meters \\
5 & Arc angle & For major curve 897 meters \\
& & For minor curve $254^{\circ}$ \\
& & For major curve $169^{\circ}$
\end{tabular}

Table 2 Morphometry of the Nawpara Beel

Different parameters of water quality of the beel were tested (Table 3 ) and reveal the health of the beel for aquaculture. ${ }^{15-18}$ Suggested optimum level of Biological Oxygen Demand (BOD), Dissolved Oxygen (DO), Chemical Oxygen Demand (COD), pH, ammonia, temperature, turbidity etc for aquaculture in ponds. DO level in Nawpara Beel is much lower than recommended level $>4 \mathrm{mg} \mathrm{L}^{-1}$.
As the fishermen co-operative society associated with the beel is in dormant for a long period, the beel is almost covered by dense hyacinth for about 6 years. That is why DO level is far below the optimum level. Optimum range of $\mathrm{pH}$ for general aquaculture is $6<$ $\mathrm{pH}<9$. In Nawpara Beel, $\mathrm{pH}$ of water is 7.12 which indicate good health of water in terms of acidity and alkalinity. Recommended BOD 
level should be $<1.6 \mathrm{mg} \mathrm{L}^{-1}$. But in this present study, the value is 3 . This again is because of eutrophication.

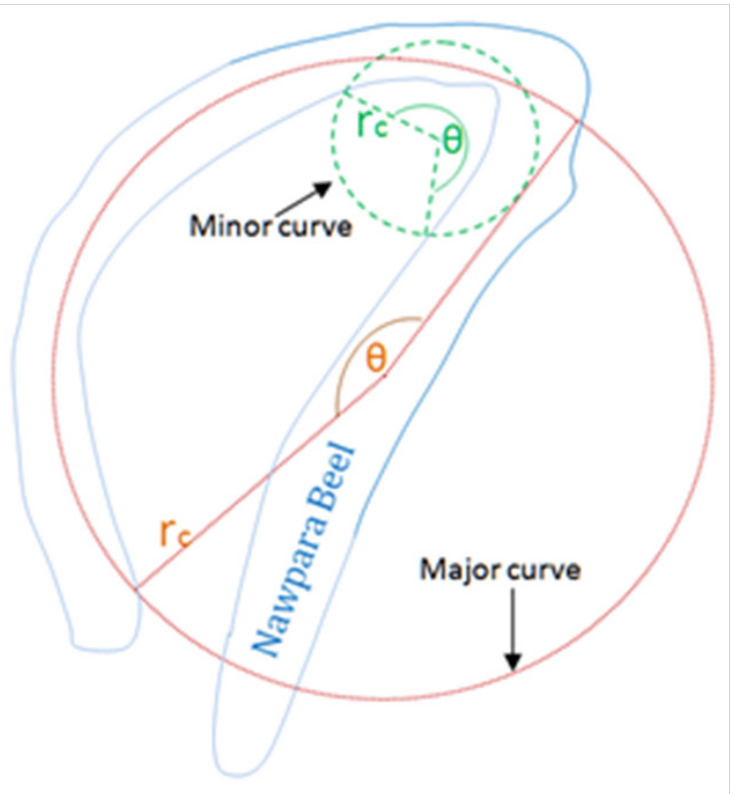

Figure I Arc between two inflexion points makes arc angle $\theta$ at centre. Higher the magnitude of $\theta$ ( 270 ) indicates acute bend of meander of parent river and origin of oxbow lake is because of neck cut-off. Lower value of $\theta$ $\left(\leq 180^{\circ}\right)$ of the oxbow lakes indicates its origin as chute cut-off. For Nawpara Beel, $\theta$ is $254^{\circ}$ which indicates its origin as neck cut-off of parent river's bend.

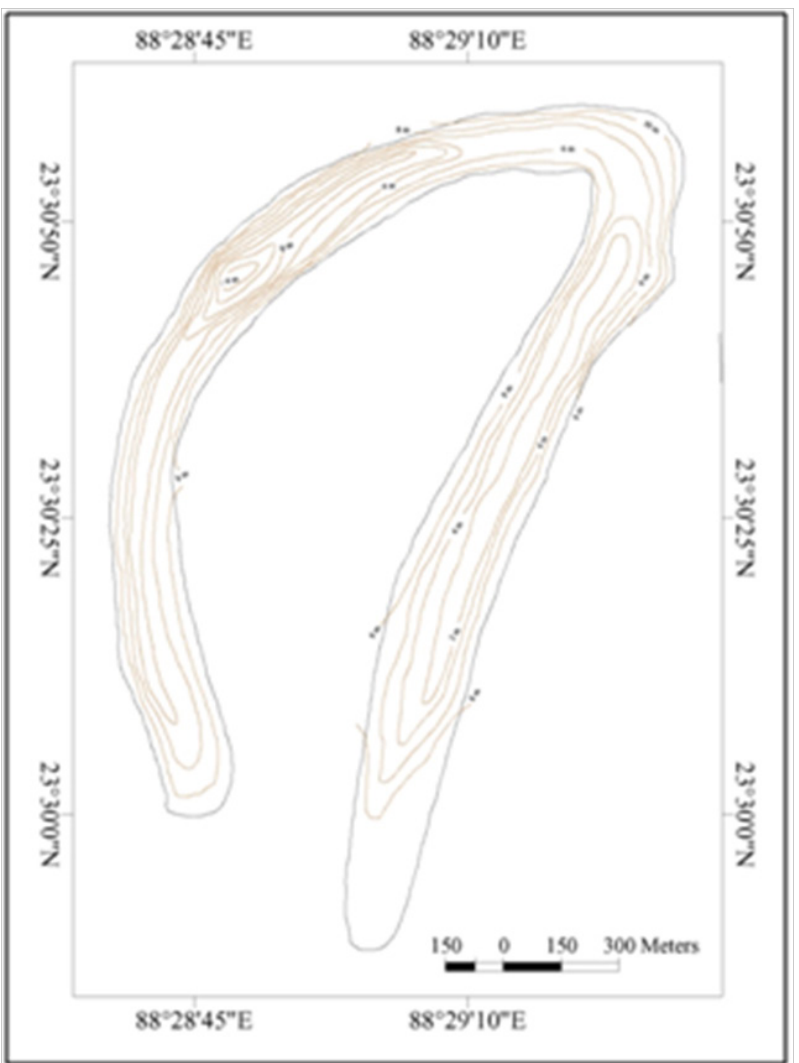

Figure 2 For the most efficient channel $w / d$ ratio is 2.54. Average $w / d$ ratio is 63.46 which indicate very shallow channel. Average $I_{w}$ of Nawpara Beel 4.85 also indicates wider channel in compare to its cross-sectional area. Mean $I_{d}$ for the beel was 0.20 which indicate lesser depth. Value of $C_{f}(24.95)$ also indicate wide shallow channel with low efficiency.
Table 3 Physical and Chemical quality of water of Nawpara Beel

\begin{tabular}{|c|c|c|c|}
\hline $\begin{array}{l}\text { Sl. } \\
\text { No. }\end{array}$ & Parameters & Result & $\begin{array}{l}\text { Test Method } \\
\text { Specification }\end{array}$ \\
\hline I & $\mathrm{pH}$ & 7.12 & $\begin{array}{l}\text { APHA } 2{ }^{\text {st }} \text { Edition, } \\
4500-\mathrm{H}-\mathrm{B}\end{array}$ \\
\hline 2 & $\begin{array}{l}\text { Total Dissolved Solids } \\
(\mathrm{mg} / \mathrm{l})\end{array}$ & 164 & $\begin{array}{l}\text { APHA } 21^{\text {st }} \text { Edition, } \\
2540 \mathrm{C}\end{array}$ \\
\hline 3 & $\begin{array}{l}\text { Total Suspended Solids } \\
(\mathrm{mg} / \mathrm{l})\end{array}$ & s 17 & $\begin{array}{l}\text { APHA 21 st Edition, } \\
2540 \text { D }\end{array}$ \\
\hline 4 & $\begin{array}{l}\text { Conductivity ( } \mu \mathrm{mhos} / \\
\mathrm{cm} \text { ) }\end{array}$ & 283.5 & $\begin{array}{l}\text { APHA } 21^{\text {st }} \text { Edition., } \\
2510 \mathrm{~B}\end{array}$ \\
\hline 5 & $\begin{array}{l}\text { Dissolved Oxygen } \\
(\mathrm{mg} / \mathrm{l})\end{array}$ & 0.29 & $\begin{array}{l}\text { APHA } 21^{\text {st }} \text { Edition, } \\
4500^{\circ} \mathrm{C}\end{array}$ \\
\hline 6 & $\begin{array}{l}\text { Chemical Oxygen } \\
\text { Demand }(\mathrm{mg} / \mathrm{l})\end{array}$ & 19 & $\begin{array}{l}\text { APHA } 21^{\text {st }} \text { Edition, } \\
5220 \mathrm{~B}\end{array}$ \\
\hline 7 & $\begin{array}{l}\text { Biological Oxygen } \\
\text { Demand }(\mathrm{mg} / \mathrm{l}) 3 \text { days }\end{array}$ & 3 & $\begin{array}{l}\text { IS } 3025 \text { (Part } \\
44): ' 1993\end{array}$ \\
\hline
\end{tabular}

APHA $21^{\text {st }}$ Edition, Name of the 3500-Fe B wetland: Nawpara APHA $21^{\text {st }}$ Bdition, Beel 4500-NO3 -E Date of sample APHA $21^{\text {st Ed }}$ collection: APHA $21^{\text {st }}$ Edition, 12.06 .2015 * 4500 - P D Analysis completed APHA 2 I $^{\text {st }}$ Edition, on: 20.06.20I 5 $3500-\mathrm{Na} B$

APHA $21^{\text {st }}$ Edition,

$3500-\mathrm{K} B$

APHA 2 I $^{\text {st }}$ Edition,

$3111 \mathrm{~B}$

I3 Cadmium as $\mathrm{Cd}(\mathrm{mg} / \mathrm{l})<0.003$

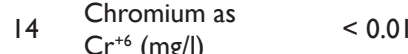

APHA $21^{\text {st }}$ Edition,

$3500-\mathrm{Cr}$ B

15 Copper as $\mathrm{C}(\mathrm{mg} / \mathrm{l}) \quad<0.025 \quad$ APHA 2 I $^{\text {st }}$ Edition,

3 III B

16 Lead as $\mathrm{Pb}(\mathrm{mg} / \mathrm{l})<0.01 \quad$ APHA 2 I $^{\text {st }}$ Edition,

3 III B

17 Nickel as $\mathrm{Ni}(\mathrm{mg} / \mathrm{l}) \quad<0.02 \quad$ APHA 2 I $^{\text {st }}$ Edition,

I8 Zink as Zn (mg/l) $0.01 \quad$ APHA 2 I $^{\text {st }}$ Edition,

Morphometry Rawson ${ }^{19}$ of the Nawpara Beel (largest and deepest wetland in the CD Block Krishnagar-II) is very good for wide variety of aquaculture. Minor constraints about some chemical properties of water may readily be removed if the beel is cleared of hyacinths. Active involvement of inhabitants on its banks may enable the beel to sustain thousands of villagers on its banks. ${ }^{20-22}$

\section{Conclusion}

Nawpara Beel is an oxbow lake originated as neck cut-off of an acute meander of the River Jalangi. Siltation has turned it into a much wide and shallow wetland in terms of channel efficiency. The beel is bathymetrically very good for variety of aquaculture but have some limitations in terms of chemical and biological properties of water.

\section{Acknowledgements}

Sincere gratitude to -Editor, Journal of Aquaculture \& Marine Biology whose valuable mail acquainted me with the journal, Reviewers, for their valuable comments and proposals, and my students. 


\section{Conflicts of interest}

No conflict of Interset.

\section{References}

1. Mitsch WJ, Gosselink JG. Wetlands. (4 $4^{\text {th }}$ edn $)$, John Wiley \& Sons, Inc., Hoboken, USA. 2007;pp.582.

2. Shaw SP, Fredine CG. Wetlands of the United States: Their extent and values to Waterfowl and other wildlife. Washington D. C. Department of the Interior, Fish and Wildlife Service, Office of River Basin Studies. Circular. 1956;39.

3. Cowardin LM, Carter V, Golet FC, et al. Classification of wetlands and deepwater habitats of the United States. U.S. Department of the Interior, Fish and Wildlife Service. 1979.

4. NWCP. Guidelines for Conservation and Management of Wetlands In India, National Wetland Conservation Programme, Conservation and Survey Division Ministry of Environment and Forests Government of India, India. 2009;p.1-45.

5. Biswas KR. Rivers of Bengal, Department of Higher Education, Govt. of West Bengal, India. 2001;p.17,54.

6. Majumder D. West Bengal District Gazetters Nadia. Govt. of West Bengal, India. 1978;p.5-16.

7. Maji S. Antardeshiya Maachh Chash, Min Bhawan, College Street, Krishnagar, Fishery Department, Nadia, Govt. of West Bengal, India. 2012.

8. Debnath C, Barman A. 'Matsya Chas Bisayak Aalochona Chakra' Nadia Zila Parishad and Fishery Department, Govt. of West Bengal, India. 2014;pp.14-18.

9. Bala G, Mukherjee A. Useful Plants Of Wetlands In Nadia District, West Bengal, 2007.

10. Julien PY. Planform geometry of meandering alluivial channels. Civil Engineering Department, Engineering Research Center, Colorado State University,USA. 1985;p.6.
11. Thorne CR, Hey RD. Direct measurements of secondary currents at a river inflexion point, Nature. 1979;280:226-228

12. Knighton AD. Asymmetry of River Channel Cross-Sections: Part I. Quantitative Indices' Earth Surface Processes and Landforms. 1981;6(6):581-588.

13. Nanson GC. Self-adjustment in rivers: Evidence for least action as the primary control of alluvial-channel form and process, Earth Surface Processes and Landforms. 2017;42(4):575-594.

14. Das BC. Modeling of most efficient channel form: a quantitative approach, Model. Earth Syst. Environ. 2015;1:15.

15. NEERI. Manual on water and waste water analysis National Environmental Research Institute, Nagpur. 1986;pp.126-129.

16. Bhatnagar A, Singh G. Culture fisheries in village ponds: a multilocation study in Haryana, India. Agric Biol J N Am. 2010;1(5):961-968.

17. Banerjea SM. Water quality and soil condition of fishponds in some states of India in relation to fish production. Indian journal of Fisheries. 196714(1-2):115-144.

18. Chand BK, Goswami A, Biswas PK, et al. Effect of stocking levels of ducks on production of Indian Major Carps in village ponds under duckfish integrated system in West Bengal state of India. Livestock Research for Rural Development. 2006;Vol.18.

19. Rawson DS. Morphometry as a dominant factor in the productivity of large lakes. International Ver Theor Ange Limnology Verh. 1955;12:164 175 .

20. Boyd CE. Sources of $\mathrm{CO}_{2}$ for nuisance blooms of algae. Weed Science. 1972;20(5):492-497.

21. Meade JW. Allowable ammonia for fish culture. Progressive Fish culture. 1985;47(3):135-145.

22. Mitsch WJ, Gosselink JG, Anderson CJ, et al. Wetland Ecosystems, John Wiley and Sons, Inc 2009;.p.9. 